\title{
Collaborative Governance and Partnerships in Policing
}

\author{
Michael Li \\ University of Massachusetts Boston, Boston, USA \\ Email:michael.li@alumni.umb.edu
}

How to cite this paper: Li, M. (2017) Collaborative Governance and Partnerships in Policing. Open Journal of Social Sciences, 5, 50-58.

https://doi.org/10.4236/jss.2017.512004

Received: November 18, 2017

Accepted: December 9, 2017

Published: December 12, 2017

Copyright $\odot 2017$ by author and Scientific Research Publishing Inc. This work is licensed under the Creative Commons Attribution International License (CC BY 4.0).

http://creativecommons.org/licenses/by/4.0/

\section{c) (i) Open Access}

\begin{abstract}
This study has reviewed past literature on policing to shed lights on how collaborative governance may be used in the police service. In sum, evidence suggests that partnership in the police service has a huge potential of benefits in managing crime and safety, but it also requires a substantial level of attention to reap such gains. This research has looked into three distinct forms of partnerships in particular; police-probation, police-community and multi-agency partnerships. Each of these initiatives has their strengths and weaknesses. The main benefit of police-probation collaboration is that it significantly enhances supervision and apprehending of the offenders. On the other hand, community policing has been found to be effective in reducing the crime rate in the society through information sharing and reporting of cases of lawbreaking in the neighborhood. A multi-agency partnership improves the efficiency of service provision but requires a significant level of vigilance and coordination to minimize chances of conflicts.
\end{abstract}

\section{Keywords}

Collaborative Governance, Policing, Public-Private Partnerships

\section{Introduction}

In order to reduce the crime rate, many law enforcement agencies have formed collaborative partnership with their communities or other government agencies. Such forms of governance structure may have a significant impact on whether and to what extent the police organizations can achieve their goals and missions. The collaboration may be established between the police and non-governmental organizations (NGOs), private firms, social service providers, religious bodies and other community members. In the traditional law enforcement, there was a limited role for the citizenry in community safety issues; however, the policing 
agencies are learning that the public can provide vital information about the criminal events in their neighborhood. Recent evidence suggests that the citizenry may become a crucial source of support to law enforcement agencies as they assist in investigations and report any illegal activities taking place in their communities [1] [2] [3]. Moreover, a collaborative form of governance among various government agencies may also significantly contribute to more effective and efficient provision of public service.

In this paper, I seek to advance our understanding about the various forms of partnerships among police, other governmental organizations, and the public by conducting a review of recent literature. Specifically, I propose and summarize the rationale for the formation of the collaborations as found in past literature. This research also explains how the collaboration and partnerships were created and whether they have achieved their goals. The paper will focus on three specific forms of partnerships: police-probation, police-community, and multi-agency partnerships.

\section{Literature Review on Various Partnerships in Policing}

\subsection{Police-Probation Partnerships}

The collaboration between the police and probation officers has existed for long. However, a revolution took place in the 1990s in Boston where the police-probation partnerships were constituted, and it was realized that such relations were useful since they were dealing with highly interrelated issues [4]. Moreover, the collaboration has improved the supervision of probationers and safety of the community. The past few years have seen various correction and law enforcement agencies come together by drawing staff from each side to form units that work hand in hand to control crime [4]. Previous studies indicate that there is a variety of such partnerships including fugitive apprehension units, information sharing collaboration, interagency problem-solving groups, specialized enforcement team and enhanced supervision section [5]. The enhanced supervision teams do not carry caseloads and hence have adequate time to oversee the probationers [4]. Such partnerships include the San Bernardino's Nightlight program, Minneapolis Anti-Violence Initiative, and Project One Voice found in New Haven. Many agencies have also come together to apprehend fugitives and even share information concerning lawbreakers [4]. A good example is the Fugitive Recovery Enforcement Team in San Francisco, California incorporates officers from the San Francisco Police Department and Parole, and Community Services Division of the California Department of Corrections [5]. Therefore the central question to ask at this juncture is whether and to what extent these partnerships are suitable in executing their duties.

Previous studies have been conducted to determine the impact of the collaboration of probation and law enforcement agencies and most of them have got to a general conclusion that such partnerships tend to improve security services in different places [4] [6]. In a study that examines the effect of Nightlight on 
city-wide arrests, evidence indicates that the crime rate decreased significantly following the partnership in San Bernardino [4]. Evidence also suggests that offenders in other comparable cities that were served by the same probation team without partnering with police did not experience such a positive impact during the same period.

It should be noted, however, that the police-probation partnership is not a panacea and may create some unintended consequences as well. For example, previous show that the mission of the organizations was somewhat "distorted" following the police-probation partnership [6]; it was found that officers from each section (correction and law enforcement) sometimes go beyond their authority. Research also indicates that having members from both sides in the same team may fix this problem. That is, mixing employees from both sides (in addition to the general partnership agreement) may deal with the role confusion for efficient service delivery [6]. This study also suggests that mission distortion is more likely when officers from different agencies overstep their mandate and thus the need for guidelines on roles and boundaries is required. A study ([7]) further observes that for proper functionality of the police-probation partnership, there should be a balance between the staff from the two organizations. On the one hand, the police department has more power and skill when dealing with enforcement than probation sections [7]. On the other hand, corrections department thrives more on the supervision and reintegration than the police.

\subsection{Police-Community Partnerships}

Community policing is a common concept of the 21 st century that was first popularized in the late 1970s but has been sustained for decades to date [8] [9] [10] [11]. Law enforcement agencies have used the collaboration with the members of the community they serve to improve the relationship with them [12]. Moreover, police-community partnerships have brought a substantial improvement in community safety in the society. A large group of past studies [12]-[18] has investigated antecedents affecting the collaboration and its effectiveness in solving the key issues faced by the community. This group of research shows that the desire of the citizens to participate in community policing program is a vital determinant of the success of such arrangements. According to [17] race and ethnicity influenced the willingness of individuals to work with police in the United States. Based on their findings, the blacks were more likely to cooperate with the law enforcement officers than the whites. Furthermore, the minority in the society had shown interest in working with the security agencies since they stood a higher chance to gain from such collaborations. In fact, such findings are surprising given the high tension between the black community and police organizations observed in many parts of the world [1] [2] [19] [20] [21]. Recent studies also suggest that the collaboration between the police and black communities may be facilitated when the proportion of black police officers is higher [1] [2] [3]. Such benefits of "representative bureaucracy" stems from the improved 
organizational integrity and ethical climate followed by an increase in organizational diversity [1] [2] [3].

Evidence also indicates that the residents who are familiar with the police officers were more likely to collaborate with the public service [17]. This evidence may suggest that the community policing program has been essential in crime reduction and creation of a safer society. The citizens tend to hold differing perceptions towards this community policing initiative; most of the citizenry supports the program, but there were people with negative perceptions. Those with negative views tend to believe that the community policing programs have limited effects on the successful collaboration between the police and community [12]. Implementation of community policing in the United States is found to be more comfortable in areas where residents believe that provision of proper security is a collective responsibility. These individuals respect the rule of law and always willing to provide all the necessary support to the officers [12]. Moreover, past research shows an increase in the number of criminal cases reported by the public in various regions in the US in the recent years as compared to the situation in the last two to three decades [22] [23]. Such evidence points towards a possible spread of this initiative globally, thereby contributing to a reduction in the crime rate internationally.

Police-community partnership has also been implemented to solve various conflicts in the society [24]. For instance, such collaborations have been found to work well in controlling domestic violence and cyber-crime. Recent research [25] of the U.S. Department of Justice reveals that the police used the information the community sources to respond to domestic violence cases. The residents are fully aware of the people living particular homes and therefore are in a suitable position to provide the information to the security agencies [24]. Such knowledge is paramount in the accessing the home and safe retrieval of the assaulted parties. The members of the community also serve as witnesses in the cases thus enhancing the process of prosecution as the law enforcement department treat domestic violence as a standard crime [18]. These sets of evidence indicate that the public and police may "coproduce" public value if certain conditions are met [1]. Evidence also indicates that a greater diversity and representativeness of police forces in terms of race is conducive to the coproduction of public service through the police-community partnership [1].

Research also indicates that police-community partnership can contribute to the police organizations' dealing with cybercrimes. Recently, cybercrime has become a primary security challenge in the United States [17]. Most cyber offenders target the private entities, and the police are only able to track such individuals after obtaining a report from the victims [26]. Furthermore, the investigating officers rely on the information provided by the victims to apprehend the criminal [26]. In sum, it is evident that police-community partnership plays an essential role in the crime eradication and minimization in the society [12].

It should be acknowledged, however, that past studies suggest that there should be a rapport between the police and community to realize such benefits 
of the partnership. In addition, most scholars have focused on the cooperation of the community side, it is worth noting that security personnel must also provide an environment that enables the public to develop confidence and trust in government and more particularly in the police [24]. Factors including mutual trust, witness protection, and proper communication channels will significantly impact on the smooth operation of the collaboration [17]. The police must assure the citizen who reports criminals and related incidents that it will keep the identity of the citizen fully confidential so that they are not harassed by the offenders [18]. Moreover, if one has to testify in the court, he or she must be provided with proper security both at home and in public domains [18]. The law enforcement agencies must also develop an efficient and effective communication mechanism to facilitate quick reporting and response to criminal events. All these factors are found to be critical in creating a successful police-community partnership.

\subsection{Multi-Agency Partnerships}

The dynamics in the twenty-first century has provided an environment where interdependence among organizations defines their success in dealing with the contemporary issues in the society [27]. Security, education, and healthcare are some of the sections that have proven that multi-agency partnerships are crucial in service delivery. In law enforcement, the police organizations oftentimes depend on many other government agencies' resource to arrest criminals. Once they have been arrested, they have to be prosecuted, and the judiciary comes in at this stage [28]. When found guilty, the correction centers are tasked with supervising them and take them through the reintegration process [29]. This simple example indicates that the police may gain from forming multi-agency partnerships to achieve their goals.

The police may also be engaged in interagency collaboration among governmental organizations that belong to seemingly different areas of service especially when they come together to deal with a particular problem in the community [30]. Previous studies examined managerial factors that must be considered in order to manage a successful multiagency partnership [30] [31] [32]. Another group of studies investigated efficiency implications of such multi-party partnerships of the police. Considering the high cost of crime mitigation and a collaborative effort, all interested parties must actively participate in the partnership in order to realize significant a cost sharing [25]. Moreover, coordination is essential in information sharing during the partnership period to avoid confusion [28] [30]. For instance, the management of the initiative must establish a clear report structure to ensure a smooth running of the program. Finally, there must be precise role specification and clarification, mainly where the mandates of the agencies are overlapping [27]. This will reduce the chances of confusion and omission of tasks in the operation of the unit.

Some other studies also argue that, despite all the benefits that come with the multi-agency collaboration, caution is required to ensure that the independence of individual organizations is not deteriorated [29]. One way of ensuring such 
independence is by drawing boundaries regarding information sharing and decision-making process [27]. The multi-agency team should be a separate entity from the original departments, for instance, a police-probation partnership should involve extracting staff from both sides to form a single unit but maintain independence from the original departments. In addition, there may be cases where certain strategic information must be kept confidential to each other unless there is a proper agreement between them to share such details. It is also critical for the newly formed group to have clear communication channels for appropriate relay from information thus avoiding conflicts and repetitions [29] [30].

\section{Conclusion}

Previous studies in public administration have shown for long the potential benefits and costs of collaborative governance, public-private partnerships, and participation [33]-[38]. This study has reviewed past literature on policing to shed lights on how collaborative governance may be used in the police service. In sum, evidence suggests that partnership in the police service has a huge potential of benefits in managing crime and safety, but it also requires a substantial level of attention to reap such gains. This research has looked into three distinct forms of partnerships in particular; police-probation, police-community and multi-agency partnerships. Each of these initiatives has their strengths and weaknesses. The main benefit of police-probation collaboration is that it significantly enhances supervision and apprehending of the offenders. On the other hand, community policing has been found to be effective in reducing the crime rate in the society through information sharing and reporting of cases of lawbreaking in the neighborhood. A multi-agency partnership improves the efficiency of service provision but requires a significant level of vigilance and coordination to minimize chances of conflicts.

\section{References}

[1] Hong, S. (2016) Representative Bureaucracy, Organizational Integrity, and Citizen Coproduction: Does an Increase in Police Ethnic Representativeness Reduce Crime? Journal of Policy Analysis and Management, 35, 11-33. https://doi.org/10.1002/pam.21876

[2] Hong, S. (2017) Does Increasing Ethnic Representativeness Reduce Police Misconduct?.Public Administration Review, 77, 195-205.

https://doi.org/10.1111/puar.12629

[3] Hong, S. (2017) Black in Blue: Racial Profiling and Representative Bureaucracy in Policing Revisited. Journal of Public Administration Research and Theory, 27, 547-561. https://doi.org/10.1093/jopart/mux012

[4] Worrall, J.L. and Gaines, L.K. (2006) The Effect of Police-Probation Partnerships on Juvenile Arrests. Journal of Criminal Justice, 34, 579-589. https://doi.org/10.1016/j.jcrimjus.2006.09.012

[5] Alarid, L.F., Sims, B.A. and Ruiz, J. (2011) Juvenile Probation and Police Partnerships as Loosely Coupled Systems: A Qualitative Analysis. Youth Violence and Juvenile Justice, 9, 79-95. https://doi.org/10.1177/1541204010374298 
[6] Murphy, D. and Worrall, J.L. (2007) The Threat of Mission Distortion in PoliceProbation partnerships. Policing: an International Journal of Police Strategies \& Management, 30, 132-149. https://doi.org/10.1108/13639510710725668

[7] Murphy, D. and Lutze, F. (2009) Police-Probation Partnerships: Professional Identity and the Sharing of Coercive Power. Journal of Criminal Justice, 37, 65-76. https://doi.org/10.1016/j.jcrimjus.2008.12.010

[8] McLaughlin, E. (1994) Community, Policing and Accountability: The Politics of Policing in Manchester in the 1980s. Avebury, Aldershot.

[9] Skogan, W.G. (1995) Community Participation and Community Policing. Center for Urban Affairs and Policy Research, Northwestern University, Evanston.

[10] Robinson, A.L. and Stroshine Chandek, M. (2000) Philosophy into Practice? Community Policing Units and Domestic Violence Victim Participation. Policing. An International Journal of Police Strategies \& Management, 23, 280-302. https://doi.org/10.1108/13639510010342985

[11] Wien, C.A. (2004) From policing to Participation: Overturning the Rules and Creating Amiable Classrooms. YC Young Children, 59, 34.

[12] Reisig, M.D. and Giacomazzi, A.L. (1998) Citizen Perceptions of Community Policing: Are Attitudes toward Police Important? Policing: An International Journal of Police Strategies \& Management, 21, 547-561. https://doi.org/10.1108/13639519810228822

[13] Ostrom, E. (1978) Citizen Participation and Policing: What Do We Know? Journal of Voluntary Action Research, 7, 102-108. https://doi.org/10.1177/089976407800700110

[14] Shearing, C. (1994) Participatory Policing: Modalities in Lay Participation. Imbizo, 1, 5-10. https://ssrn.com/abstract=2832112 https://doi.org/10.2139/ssrn.2832112

[15] Neyroud, P. (2001) Public Participation in Policing. Institute for Public Policy Research, London.

[16] Simmons, K.C. (2009) New Governance and the New Paradigm of Police Accountability: A Democratic Approach to Police Reform. Catholic University Law Review, 59, 373.

[17] Wehrman, M.M. and De Angelis, J. (2011) Citizen Willingness to Participate in Police-Community Partnerships: Exploring the Influence of Race and Neighborhood Context. Police Quarterly, 14, 48-69. https://doi.org/10.1177/1098611110393134

[18] Brewer, R. and Grabosky, P. (2014) The Unraveling of Public Security in the United States: The Dark Side of Police-Community Co-Production. American Journal of Criminal Justice, 39, 139-154. https://doi.org/10.1007/s12103-012-9194-y

[19] Hong, S. (2015) Ethnic Diversity in Public Organizations and Public Service Performance: Empirical Investigation. In: Academy of Management Proceedings, Vol. 2015, Academy of Management, 11334. https://doi.org/10.5465/AMBPP.2015.235

[20] Cohen, P.N. (2017) Black and Hispanic Representation in Policing: Organizational and Local Labor Market Context.

[21] Shjarback, J.A., Pyrooz, D.C., Wolfe, S.E. and Decker, S.H. (2017) De-Policing and Crime in the Wake of Ferguson: Racialized Changes in the Quantity and Quality of Policing among Missouri Police Departments. Journal of Criminal Justice, 50, 42-52. https://doi.org/10.1016/j.jcrimjus.2017.04.003

[22] Weisburd, D., Telep, C.W. and Lawton, B.A. (2014) Could Innovations in Policing Have Contributed to the New York City Crime Drop Even in a Period of Declining 
Police Strength? The Case of Stop, Question and Frisk as a Hot Spots Policing Strategy. Justice Quarterly, 31, 129-153. https://doi.org/10.1080/07418825.2012.754920

[23] Kappeler, V.E. and Potter, G.W. (2017) The Mythology of Crime and Criminal Justice. Waveland Press.

[24] Breen, M.E. and Johnson, B.R. (2007) Citizen Police Academies: An Analysis of Enhanced Police-Community Relations among Citizen Attendees. The Police Journal, 80, 246-266. https://doi.org/10.1350/pojo.2007.80.3.246

[25] Reuland, M., Morabito, M.S., Preston, C. and Cheney, J. (2006) Police-Community Partnerships to Address Domestic Violence. US Department of Justice COPS Office.

[26] Levi, M. and Leighton Williams, M. (2013) Multi-Agency Partnerships in Cybercrime Reduction: Mapping the UK Information Assurance Network Cooperation Space. Information Management \& Computer Security, 21, 420-443. https://doi.org/10.1108/IMCS-04-2013-0027

[27] Smith Stover, C. (2012) Police-Advocacy Partnerships in Response to Domestic Violence. Journal of Police Crisis Negotiations, 12, 183-198. https://doi.org/10.1080/15332586.2012.717031

[28] Evans, E. (2015) Police/Probation Partnerships-The Anticipated Impact of “Transforming Rehabilitation". International Journal of Emergency Services, 4, 194-211. https://doi.org/10.1108/IJES-01-2015-0004

[29] Gilling, D.J. (1994) Multi-Agency Crime Prevention: Some Barriers to Collaboration. The Howard Journal of Crime and Justice, 33, 246-257. https://doi.org/10.1111/j.1468-2311.1994.tb00810.x

[30] Kelman, S., Hong, S. and Turbitt, I. (2012) Are There Managerial Practices Associated with the Outcomes of an Interagency Service Delivery Collaboration? Evidence from British Crime and Disorder Reduction Partnerships. Journal of Public Administration Research and Theory, 23, 609-630. https://doi.org/10.1093/jopart/mus038

[31] Kelman, S. and Hong, S. (2014) This Could Be the Start of Something Big: Linking Early Managerial Choices with Subsequent Organizational Performance. Journal of Public Administration Research and Theory, 25, 135-164. https://doi.org/10.1093/jopart/muu010

[32] Kelman, S. and Hong, S. (2016) "Hard," "Soft," or “Tough Love" Management: What Promotes Successful Performance in a Cross-Organizational Collaboration? International Public Management Journal, 19, 141-170. https://doi.org/10.1080/10967494.2015.1114546

[33] Ansell, C. and Gash, A. (2008) Collaborative Governance in Theory and Practice. Journal of Public Administration Research and Theory, 18, 543-571. https://doi.org/10.1093/jopart/mum032

[34] Emerson, K. and Nabatchi, T. (2015) Evaluating the Productivity of Collaborative Governance Regimes: A Performance Matrix. Public Performance \& Management Review, 38, 717-747. https://doi.org/10.1080/15309576.2015.1031016

[35] Koliba, C., Meek, J.W. and Zia, A. (2010) Governance Networks in Public Administration and Public Policy. CRC Press.

[36] Hong, S. (2015) Citizen Participation in Budgeting: A Trade-Off between Knowledge and Inclusiveness? Public Administration Review, 75, 572-582.

https://doi.org/10.1111/puar.12377 
[37] Hong, S. (2016) When Does a Public-Private Partnership (PPP) Lead to Inefficient Cost Management? Evidence from South Korea's Urban Rail System. Public Money \& Management, 36, 447-454. https://doi.org/10.1080/09540962.2016.1206755

[38] Hong, S. and Kim, T.K. (in press) Public-Private Partnership Meets Corporate Social Responsibility: The Case of H-Jump School. Public Money \& Management. 